\title{
Kynotherapy as a method of supporting the development of independence of children with Down syndrome
}

\author{
Mariusz Korczyński ${ }^{1}$, Judyta Popiołek ${ }^{1}$ \\ ${ }^{1}$ Vincent Pol University, Lublin
}

\begin{abstract}
More and more therapists, teachers and parents are becoming interested kynotherapy (dog therapy). It has been successfully used in pedagogical therapy, rehabilitation, psychotherapy and rehabilitation of children and adults. In the case of children with disabilities it is also a source of joy and pleasure. A dog used in the classroom - as a kind of "co-therapist" - makes the atmosphere distinctly unique and exceptional, thereby offering opportunities unknown in other types of therapy. A therapy dog may play a creative role in a child's world, in which he or she will acquire and develop new cognitive and social skills.

This article attempts to evaluate the effectiveness of kynotherapy in supporting the development of independent living people with Down syndrome in quantitative terms. The article presents the results of the tests conducted prior to and after the implementation of the ten-month kynotherapy programme in an eight-person group of children with Down syndrome, in which seven subjects suffered from moderate intellectual disability and one - severe intellectual disability. The study was conducted with the use of a panel of observations and technique of the authors' own design as a research tool, that is Social Functioning Sheet diagnosis.

The analysis of the results revealed a significant and, in some cases, considerable improvements in the analysed behaviours that are indicative of ,self independence" test, thus indicating the effectiveness of this method in improving and reducing deficits in people with Down syndrome.
\end{abstract}

Key words: Kynotherapy, children, Down syndrome

\section{Introduction}

One of the main aims of rehabilitation is supporting the development of independency of intellectually disabled children, including children with Down syndrome.

The literature defines independence as the readiness to undertake tasks based on one's activities and it stems from the willingness to act and the acceptance of the goals [1]. It is associated with such concepts as autonomy, self-actualization, self-assessment, emancipation, freedom, and self-determination $[2,3]$.

Supporting the development of independence of children with intellectual disability, including Down syndrome, may be difficult, since oftentimes the children's physical, intellectual, and emotional state inhibits them from meeting the standards of rationality and responsibility. These children cannot be fully independent in all areas of life. Shaping their independence means introducing a certain dynamics of thinking that enables the child's self-development: the understanding of the meaning of the stimulus, and shaping critical approaches [4]. A person with disability should first take part in decision-making processes in order to be able to make decisions on their own; he/she should co-decide so that he/she is able to make independent decisions. Supporting the development of independence in a child with Down syndrome is a form of interaction between the child and the therapist grounded on exerting influence but excluding pressure and compulsion. The literature often discusses the shaping of the child's environment, creating conditions that support the child's development, offering different stimuli, and encouraging child's activity $[5,6,7,8]$. One of the ways to "shape" the child's environment is the introduction of a dog that initiates contacts, activates and stimulates the child's senses. The presence of a dog, a co-therapist, during classes contributes to the creation of a unique, specific and amazing atmosphere, and hence offers unique therapeutic opportunities [9]. The studies conducted among children with Down syndrome concerning the benefits of the interaction with dogs indicate the development of positive behaviours (verbal and non-verbal) regarding the child's contact with the teacher and the dog, the reduction of negative behaviours, and the improved social interactions with other children $[10,11,12]$. 
These positive effects can be achieved through, among others, kynotherapy (dog therapy) sessions. If properly planned and directed, such sessions help to obtain given rehabilitation, therapeutic, and educational effects [13]. A proper therapy supports multidisciplinary development of a child and improves his/her cognitive, emotional, motivational, and motor functions $[14,15,16,17]$.

\section{The authors' research}

The aim of the research was to establish the scope of changes as far as independence of children with Down syndrome is concerned among the participants of a ten-month kynotherapy programme. The research established the factors of children's independence on the basis of certain behaviours (tasks) exhibited by them during kynotherapy sessions. These were: "the child focuses on the performed task", "the child wants to participate in the therapy on his/her own", "the child feeds the dog with the left and right hand", "the child combs the dog", "the child puts on and takes off the shoes", "the child leashes and unleashes the dog", "the child requires constant care and supervision during the session", "the child signals the needs", "the child puts the toys and aids back in the box" and "the child sees the therapist and the dog off after the session".

The study attempted to answer the following question: whether and to what extent the independence and autonomy of children with Down syndrome participating in kynotherapy have changed?

The research was conducted with the use of a panel study that employed observation and the Social Functioning Assessment Sheet (prepared by the authors of the study). The study was carried out between September 2010 and June 2011 as a part of the "World Closer to Me, Me Closer to the World" project completed in the 2nd Special Training and Education Centre in Lublin.

The classes were taught by a kynotherapy specialist who introduced children to two dogs: Amazonka, a female Irish Setter, certified therapy dog that passed the exam at the Polish Kynotherapy Association, and Fany - a female Cavalier King Charles Spaniel, in training to become a therapy dog. The lesson plans were prepared by the authors of the study and were tailored to the needs and possibilities of the children; they also took into account the desired goals in the field of social functioning.

The level of independence was assessed before and after the completion of kynotherapy program- me by a group of three competent raters - pedagogue, educator, and kynotherapist. The raters assessed the independence levels on the Sheet and the results underwent a comparative analysis. The tools used in the analysis included non-parametric Wilcoxon signed-rank test used for the repeated measurement of the same variable in different conditions.

The evaluation of the behaviours employed the following scale: 5 - always, 4 - often, 3 - sometimes, 2 - rarely, 1 - never. It enabled the establishment of the following levels concerning the analysed behaviours: 1-2,25 - low - poor skills, 2,25-3,75 - average - average skills, 3,75-5,0 - high - good skills.

The article presents the results of the research conducted on a group of eight children with Down syndrome. Of the children, seven suffered from moderate intellectual disability and one from severe intellectual disability (J.P.). All subjects were first graders in primary school and they all attended other forms of therapy, mainly music-based movement therapy and sensory integration therapy. They all came from nuclear families of good financial status.

\section{Analysis and interpretation of the results}

The analysis of the behaviours concerning "independence" of the subjects consisted in the comparison of the average results regarding all adopted indicators.

The analysis revealed a visible average increase in skills concerning the analysed behaviours in the majority of children (Graph 1). The biggest increase - from 2.4 to 4.0 - was observed in J.P., a child with severe intellectual disability; J.P.s skills improved from the lower average to a good, satisfactory level. Also high increase was observed in D.S. from 1 to 2.1. This person's skills increased only slightly, yet their initial level was the lowest (1), while the final approximated the average (2.1). The final results were higher than the results achieved before the implementation of kynotherapy. The diagrams illustrate the initial and final results obtained before and after the kynotherapy programme. The lines are almost parallel, which suggest the even increase of the independence-related behaviours. 
Graph 1. Results achieved by the subjects with Down Syndrome in the "independence" category

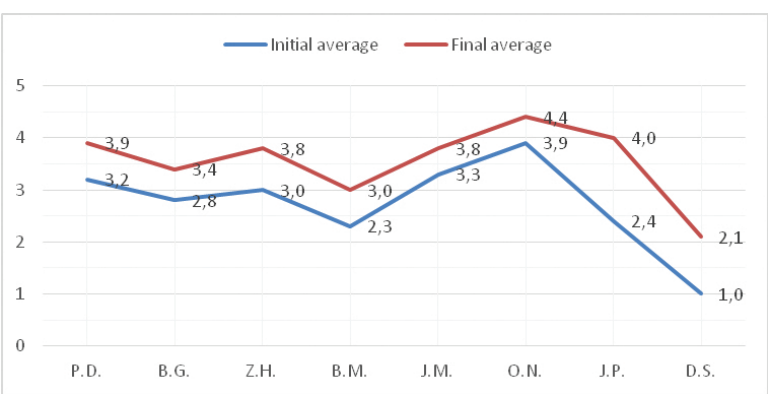

Source: own research

It can be noticed, therefore, that the subjects with moderate and severe disability exhibited an improvement as far as behaviours in the field of "independence" are concerned.

The comparative analysis of the collected data (Table 1), that is the average results of the study subjects, obtained with the use of Wilcoxon test concerning the "independence" before and after the completion of the kynotherapy programme revealed significant positive differences. Comparing the value of " $p$ " for these behaviours $(\mathrm{p}<0.04)$ in Wilcoxon signed-rank test based on the statistics with the significance level $\alpha=0.05$, it may be concluded that there exist a statistically significant difference in the level of ability between the initial and final test as far as the following behaviours are concerned: "the child wants to participate in the therapy", "the child feeds the dog with the left and right hand" and "the child puts on and takes off the shoes".

Table 1. Comparison of the initial and final levels of specific behaviours in the "Independence" category of the children with Down syndrome

\begin{tabular}{|c|c|c|}
\hline \multirow[t]{2}{*}{ Behaviours } & \multicolumn{2}{|c|}{ Wilcoxon test } \\
\hline & $\mathrm{Z}$ & $\mathrm{p}$ \\
\hline The child focuses on the performed task & 1.60 & 0.11 \\
\hline The child wants to participate in the therapy & 2.02 & 0.04 \\
\hline The child feeds the dog with the left and right hand & 2.02 & 0.04 \\
\hline The child combs the dog & 1.82 & 0.07 \\
\hline The child puts on and takes off the shoes & 2.02 & 0.04 \\
\hline The child leashes and unleashes the dog & 1.60 & 0.11 \\
\hline $\begin{array}{l}\text { The child requires constant care and supervision during the } \\
\text { session }\end{array}$ & 1.34 & 0.18 \\
\hline The child signals the needs & 1.63 & 0.11 \\
\hline The child puts the toys and aids back in the box & 1.83 & 0.07 \\
\hline The child sees the therapist and the dog off after the session & 1.83 & 0.07 \\
\hline
\end{tabular}

$\mathrm{p}<0,05-$ significant level

$0,05<\mathrm{p}<0,1-$ level approximating the significant / close to significant
The data from Graph 1, 2, 3, and 4, reveal a significant increase in the analysed skills. An important increase in skills was observed also as far as the following behaviours are concerned: "the child combs the dog", "the child puts the toys and aids back in the box" and "the child sees the therapist and the dog off after the session"; the significance level approximated the significant $(\mathrm{p}>0,07)$.

The initial results achieved by the subjects concerning "the child wants to participate in the therapy" behaviour (Graph 2) allow for a conclusion that $50 \%(\mathrm{M}=\mathrm{Q} 1=2.0)$ of the subjects exhibited poor (low) motivation for participation in the therapy, 25\% (Q3=3.0) - average motivation, while the remaining $25 \%$ showed strong motivation ( $\max$ $=4.0$ ). However, the final results revealed that the group became more homogenous (the minimum -maximum scope has changed from 1.0-4.0 to 2.04.0 ), and the level of the skills concerning the analysed behaviour increased, since none of the subjects achieved the lowest results (1.0), 25\% of the subject did not change the level of motivation $(\mathrm{Q} 1=2.0)$, while $75 \%$ obtained average or high results ( $25 \%$ of them were high). Therefore, the number of children who wanted to participate in the therapy increased.

Graph 2. "The child wants to participate in the therapy" behaviour - comparison of the results of subjects with Down syndrome

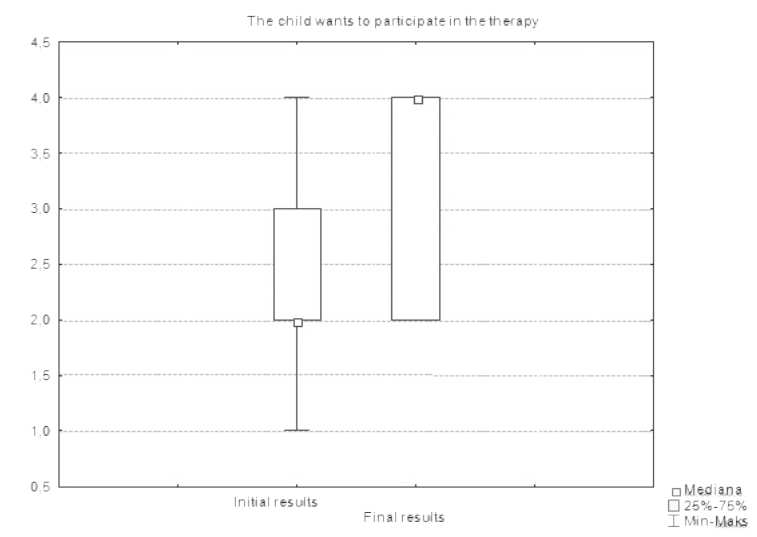

Source: own research

A similar trend can be observed in "the child feeds the dog with the left and right hand" behaviour (Graph 3). According to the initial results, 25\% of the subjects did not exhibit such skill (Q1=2.0), $50 \%$ of the subjects exhibited average skills (from 2.0 to 4.0 ), while $25 \%$ showed great skills $(\mathrm{Q} 3=4.0$ ). After the kynotherapy sessions the scores significantly improved and they were as follows: $25 \%$ exhibited poor skills leaning towards average $(\mathrm{Q} 1=3.0)$, another $25 \%$ showed average and good skills $(M=4.0)$, while $50 \%$ of the subjects exhibited good skills (Q3=5.0). 
Graph 3. "The child feeds the dog with the left and right hand" behaviour - results of subjects with Down

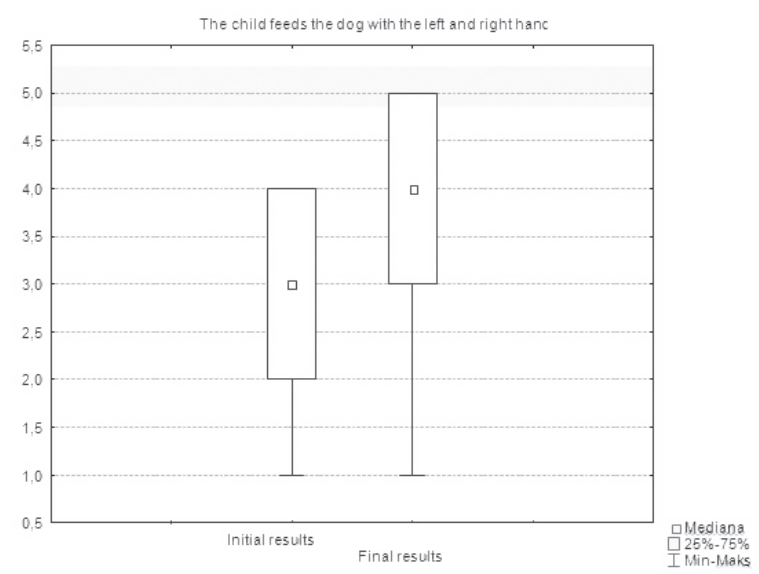

syndrome comparison of the

Source: own research

Even bigger differences could be observed as far as "the child puts on and takes off the shoes" behaviour (Graph 4). Prior to kynotherapy, the skills concerning putting on and taking off shoes were poor and average in $50 \%$ of the subjects $(M=3.0=Q 1)$, average in $25 \%$ of the subjects (Q3=4.0), and high in the remaining $25 \%$.

Graph 4. "The child puts on and takes off the shoes" behaviour - comparison of the results of subjects with Down syndrome

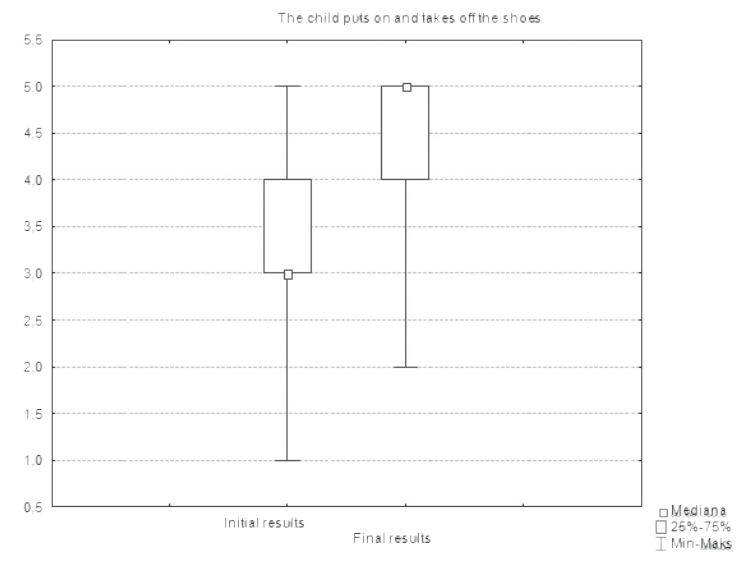

Source: own research

After the programme, the results significantly improved. None of the subjects showed lacks as far as this behaviour is concerned (Min=2.0), 25\% of the subjects showed the skill on the average level, while the remaining $75 \%$ - on a high level.

It should be noted that the skills concerning the remaining behaviours also increased, however the differences were not so significant. These skills included: "the child puts the toys and aids back in the box", "the child sees the therapist and the dog off after the session" and "the child combs the dog", in which $\mathrm{p}>0,07$ approximated the significant level. As far as the remaining behaviours are concerned, the skills also increased, however the increase was too small to be treated as significant.

A comparative analysis of the initial and final scores concerning the independence-related behaviours led to very interesting conclusions. The analysis was conducted with the use of line graphs illustrating the distribution of the scores before and after the ten-month kynotherapy programme.

The majority of P.D.'s initial results were of average (3) and lower-high (4) level (Graph 5). In the three behaviours: "the child wants to participate in the therapy" (2), "the child requires constant care and supervision" (2) and "the child sees the therapist and the dog off after the session" (2), the skills were considered as unsatisfactory. After the kynotherapy programme, the skills significantly improved. The biggest positive change regarded the high increase in the skills connected with "the child wants to participate in the therapy" behaviour (from 2 to 4); it changed from unsatisfactory to satisfactory level. Also in the case of the remaining behaviours whose scores were the lowest, the subject achieved a bit lower, but still positive increase in the skills - from the low to average level.

Graph 5. Comparison of the initial and final results concerning specific behaviours in the "independence" category by P.D. - a subject with moderate Down syndrome

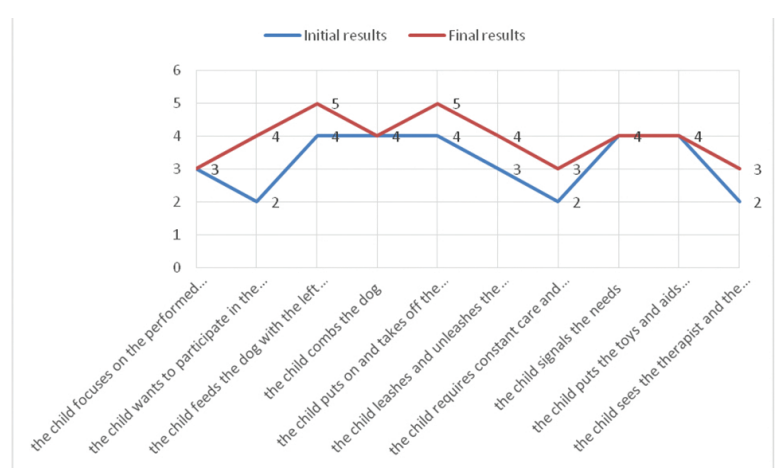

Source: own research

P.D. achieved the highest scores (5) in two types of behaviours ("the child feeds the dog with the left and right hand" and "the child puts on and takes of the shoes"), which may prove that the child fully developed these skills. However, the improvement was not observed in all types of behaviours. In case of four behaviours, the initial and the final results were the same, and the results for one behaviour 
deteriorated. These include: "the child focuses on the performed task" (remained on the average level), "the child combs the dog", "the child signals the needs" and "the child puts the toys and aids back in the box" (remained on satisfactory level). The regression concerned the increased frequency of the "child requires constant care and supervision during sessions" behaviour (from 2 to 3 ). However, the significant improvement in the most neglected behaviours can be considered as the most important.

Both the initial and the final scores achieved by another subject (B.G.) also indicated the increase in the skills in the majority of the analysed behaviours (Graph 6). These include "the child focuses on the performed task" (from 2 to 3 ), "the child wants to participate in the therapy" (from 1 to 2 ), "the child combs the dog" (from 2 to 3 ), "the child puts on and takes off the shoes" (from 4 to 5), "the child puts the toys and aids back in the box" (from 3 to 4 ), and "the child sees the therapist and the dog off after the session" (from 3 to 4 ). The improvement in these behaviours may seem small, but nevertheless it was significant. It triggered some positive changes, especially in those behaviours that were at the lowest level before the programme - behaviours concerning concentration, motivation, and therapeutic activities. The remaining four behaviours, namely: "the child feeds the dog with the left and right hand" (3), "the child leashes and unleashes the dog" (3), "the child requires constant care and supervision" (2), and "the child signals the needs" (5) did not undergo any change; it should be noted that the last behaviour could not have been improved, since before the program the child achieved the highest possible result in this area. In case of the remaining behaviours, stagnation was observed.

Graph 6. Comparison of the initial and final results concerning specific behaviours in the "independence" category in B.G. - a subject with moderate Down syndrome

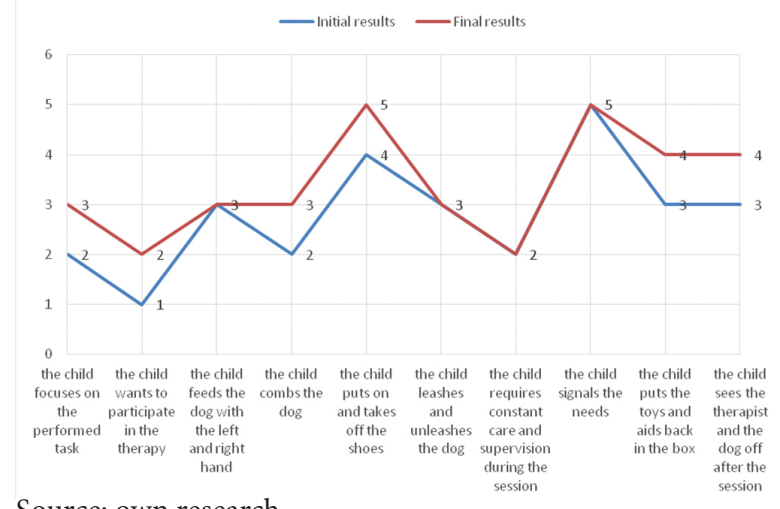

Source: own research
The analysis of the Z.H.s scores also indicated the skills' improvement in the following six behaviours: "the child wants to participate in the therapy" (from 3 to 4 ), "the child feeds the dog with the left and right hand" (from 4 to 5), "the child combs the dog" (from 4 to 5), "the child puts on and takes off the shoes" (from 3 to 4 ), "the child puts the toys and aids back in the box" (from 2 to 3 ), and "the child sees the therapist and the dog off after the session" (from 1 to 3 ). The greatest improvement was noted in the last behaviour - from the lowest level (never) to average (sometimes). It should be also emphasized that the improvement of the behaviour that was assessed as the poorest before the programme ("the child puts the toys and aids back in the box"), improved from unsatisfactory to average. However, one behaviour - "the child requires constant care and supervision during the session" deteriorated. The frequency of this behaviour unfortunately increased. In the case of the remaining behaviours the differences are less significant, yet they show a positive tendency, especially as far as the motivation for therapy and independence in the controlled activities are concerned.

The behaviours that remained unchanged include: "the child focuses on the performed task" (3), "the child leashes and unleashes the dog" (4), and "the child signals the needs" (4). First of them remained at the average level, the two remaining ones - at the satisfactory level. It can be observed, therefore, that Z.H.'s participation in the kynotherapy programme translated into the improvement of specific behaviours in the "independence" category.

Graph 7. Comparison of the initial and final results concerning specific behaviours in the "independence" category in Z.H. - a subject with moderate Down syndrome

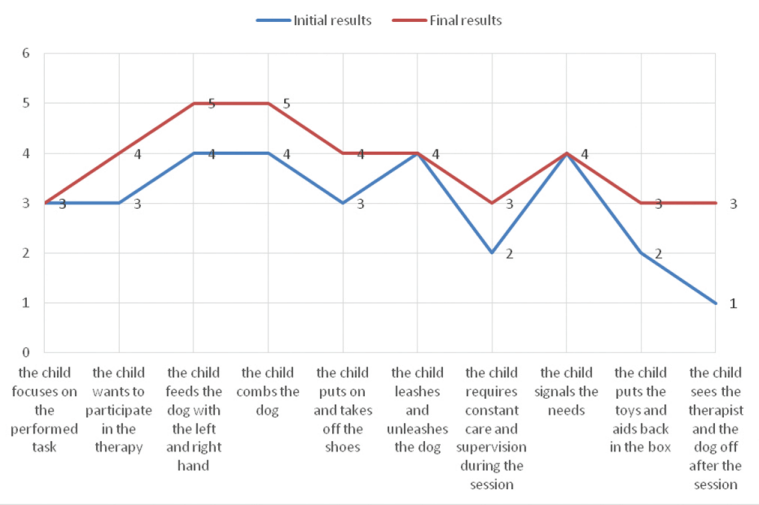

Source: own research

The comparison of the initial and final results of another subject - B.M. also indicated positive changes in the analysed field of behaviour (Graph 
8). The change concerned the following behaviours: "the child focuses on the performed task" (from 2 to 3), "the child wants to participate in the therapy" (from 2 to 3), "the child feeds the dog with the left and right hand" (form 2 to 3 ), "the child combs the dog" (from 2 to 3), "the child puts on and takes off the shoes" (from 3 to 4 ), "the child signals the needs" (from 4 to 5), and "the child puts the toys and aids back in the box" (from 3 to 4 ). The differences were small, around 1 point on the scale, yet they significantly changed the subject's level of independent functioning; the first four increased from the low, unsatisfactory, to an average; the three remaining were on high, satisfactory level. It should be noted that the behaviour "the child signals the needs" was assessed as high (always). No changes were noted as far as the three following behaviours are concerned: "the child leashes and unleashes the dog" (2), "the child sees the therapist and the dog off after the session" (2), and "the child requires constant care and supervision during the session" (1). The first two behaviours were on unsatisfactory level, however the last one was by all means desirable. Therefore, it may be concluded that despite some changes concerning concentration, independence, motivation for therapy, and order, the functioning in the "independence" category was generally average, low.

Graph 8. Comparison of the initial and final results concerning specific behaviours in the "independence" category in B.M. - a subject with moderate Down syndrome

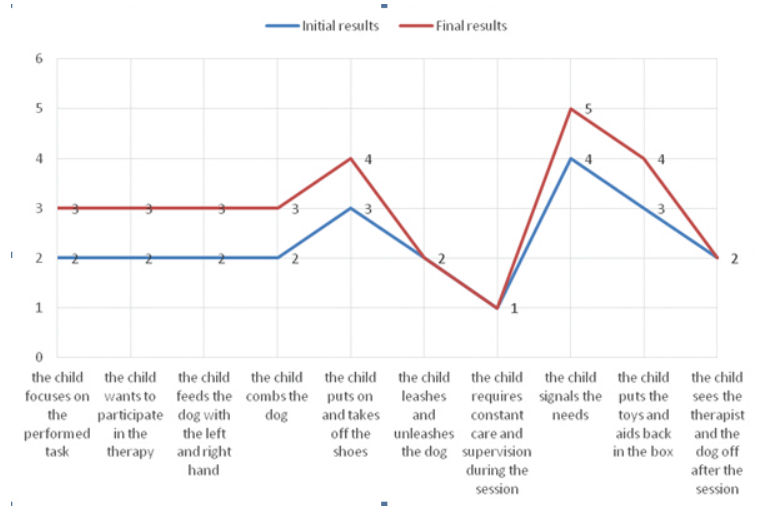

Source: own research

The analysis of J.M.'s results shows a different picture (Graph 9). Although no regressive phenomena were observed, the number of behaviours that did not improve increased to five. The progression of the analysed behaviours ("the child wants to participate in the therapy" (from 3 to 4), "the child feeds the dog with the left and right hand" (from 3 to 4), "the child signals the needs" (from
4 to 5), "the child puts back toys and aids" (from 3 to 4), and "the child sees off the therapist and the dog after the session" (from 3 to 4)) was small, yet indicative of a positive tendency. All these behaviours showed the improvement from the average, poor level to high, satisfactory level. Some of the behaviours remained unchanged, namely: "the child focuses on the performed task" (3), "the child combs the dog" (4), "the child puts on and takes off the shoes" (5), "the child leashes and unleashes the dog" (4), and "the child requires constant care and supervision during the session" (1), yet their improvement was difficult since the results were high before the implementation of the kynotherapy programme. The low scale of positive changes and considerably high number of behaviours that stagnated result most probably from the fact that J.M. is a person generally well functioning in the "independence" category. Therefore, one should not expect significant changes in the areas marked as satisfactory before the programme. The lack of improvement may also result from the fact that due to health problems, the subject missed many classes.

Graph 9. Comparison of the initial and final results concerning specific behaviours in the "independence" category in J.M. - a subject with moderate Down syndrome

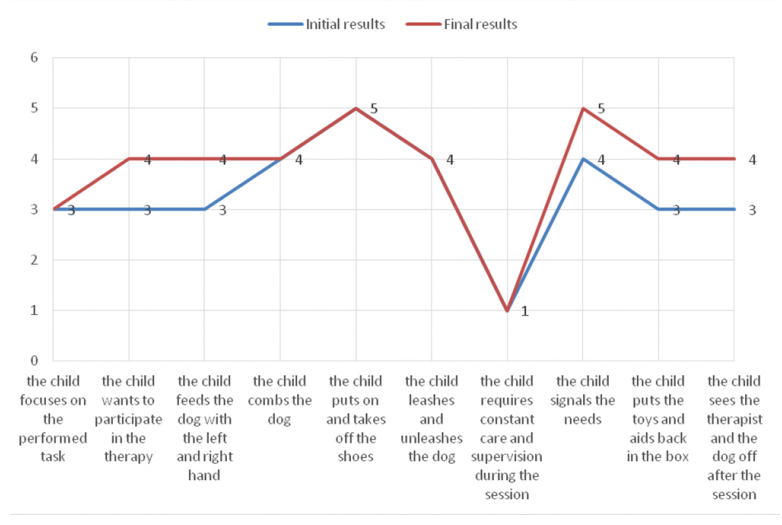

Source: own research

The subject that functioned best in the field of "independence and autonomy" was O.N. This person's initial results were high in eight out of ten behaviours, and two were average (Graph 10). The final results indicate O.N.'s skills as far as the behaviours shaped in the ten-month kynotherapy programme are concerned. The only behaviour that did not improve was "the child requires constant care and supervision during the session" and O.N. still requires constant care and supervision. 
Positive results that manifest themselves in the increase in skills were observed as far as the following behaviours are concerned: "the child feeds the dog with the left and right hand" (from 4 to 5), "the child combs the dog" (from 4 to 5), "the child puts on and takes off the shoes" (from 4 to 5), "the child leashes and unleashes the dog" (form 3 to 4 ) and "the child sees the therapist and the dog off after the session" (from 3 to 4 ). The first three results were on high, satisfactory level, the fourth increased from the average, poor to high, satisfactory. The behaviours whose levels did not change include: "the child focuses on the performed task" (4), "the child wants to participate in the therapy" (4), "the child signals the needs" (4), and "the child puts the toys and aids back in the box" (4). As far as these behaviours are concerned, the subject achieved high scores already before the participation in the therapy.

Graph 10. Comparison of the initial and final results concerning specific behaviours in the "independence" category in O.N. - a subject with moderate Down syndrome

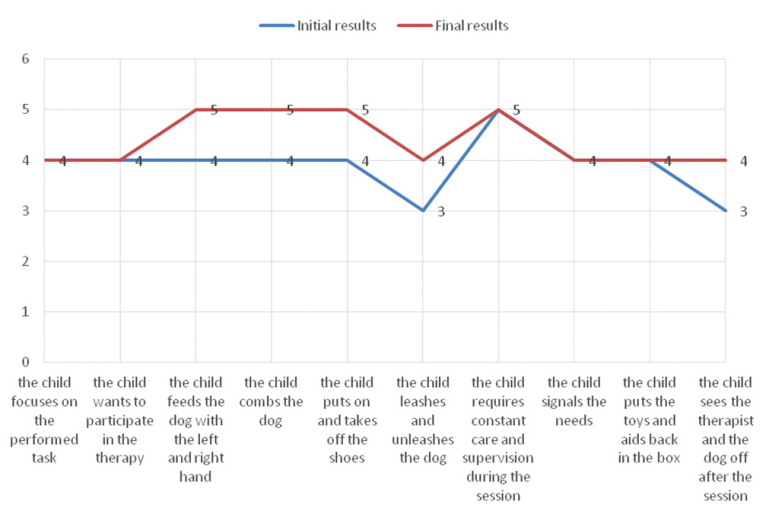

Source: own research

The greatest effects of kynotherapy were observed in J.P. (Graph 11), whose skills improved in nine out of ten behaviours. The only behaviour that did not improve was "the child requires constant care and supervision during the session" (4). The initial results concerning the improved behaviours were low, unsatisfactory (2) for seven behaviours, which basically meant very poor skills. The remaining two were initially evaluated as average, poor skills. The situation changed considerably after the programme.
Graph 11. Comparison of the initial and final results concerning specific behaviours in the "independence" category in J.P. - a subject with severe Down syndrome

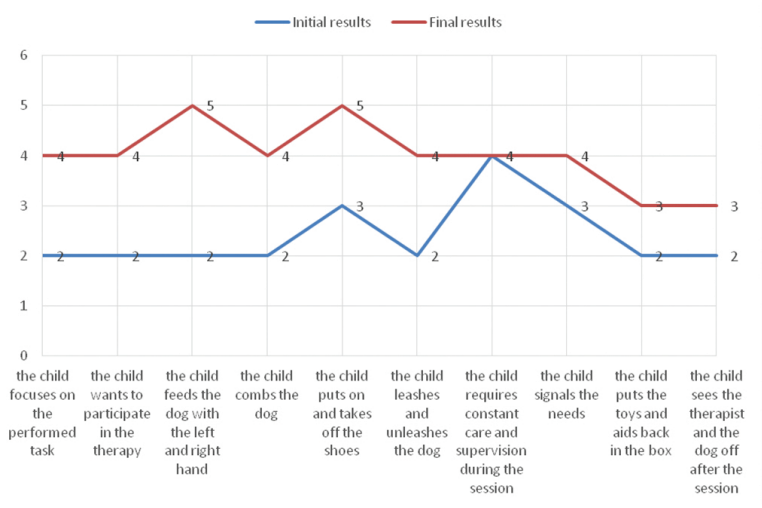

Source: own research

The six behaviours, namely: "the child focuses on the performed task" (from 2 to 4), "the child wants to participate in the therapy" (from 2 to 4 ), "the child feeds the dog with the left and right hand" (from 2 to 5), "the child combs the dog" (from 2 to 4), "the child puts on and takes off the shoes" (from 3 to 5), and "the child leashes and unleashes the dog" (from 2 to 4 ) showed significant improvement from unsatisfactory, poor levels to satisfactory, high levels. The two behaviours: "the child feeds the dog with the left and right hand" and "the child puts on and takes off the shoes" reached the highest level (5, always), which may show fully developed behaviour. The three remaining types: "the child signals the needs" (from 3 to 4), "the child puts the toys and aids back in the box" (from 2 to 3 ), and "the child sees the therapist and the dog off after the session" (from 2 to 3 ) exhibited a smaller, yet equally important, improvement; the first behaviour showed the increment from average to high, the two remaining - from low to average. Only "the child requires constant care and supervision during the session" (4) behaviour did not change and was generally unsatisfactory. It may be assumed, therefore, that the kynotherapy programme significantly improved the subject's functioning in the "independence" category, especially as far as concentration, dog-feeding autonomy, and motivation for therapy are concerned. It was even more significant since the person suffered from severe intellectual disability. It should be remembered that such richness of positive changes in J.P. might also be a result of a parallel participation in different forms of therapy, such as music-based movement therapy, movement therapy, communication therapy, and corrective and compensatory therapy. 
The highest number of improved behaviours was observed in D.S. (Graph 12), yet these were mostly small changes within the low-level results.

Graph 12. Comparison of the initial and final results concerning specific behaviours in the "independence" category in D.S. - a subject with moderate Down syndrome

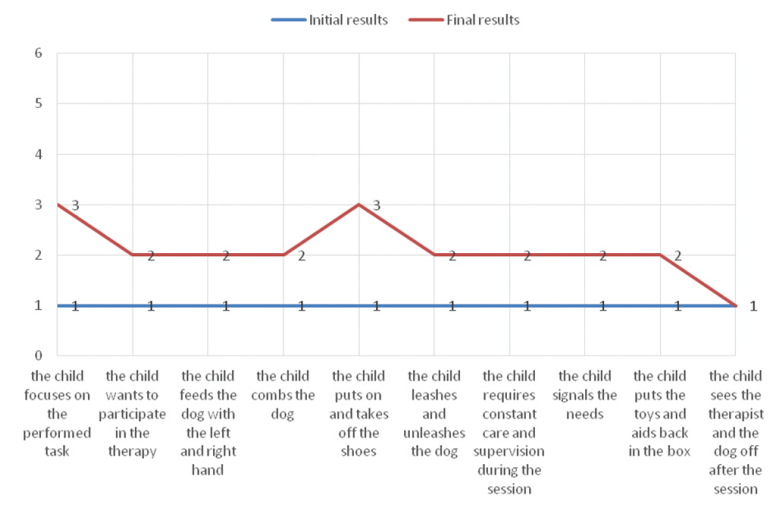

Source: own research

The initial results indicated a total lack of certain behaviours before the kynotherapy programme. All results were on the lowest possible level (1), which indicated that person did not exhibit any of the behaviours. The results obtained after the ten -month programme revealed changes in nine out of ten behaviours. The only behaviour that did not show any improvement was "the child sees the therapist and the dog off after the session" (1).

The highest improvement was observed in the following behaviours: "the child focuses on the performed task" (from 1 to 3), and "the child puts on and takes off the shoes" (from 1 to 3 ), from the lowest to average level; the remaining increments of skills were very small, and remained low and unsatisfactory. However, one behaviour "the child requires constant care and supervision during the session" regressed and the frequency of the behaviour slightly increased (from never to rarely). The lowest possible results obtained before the programme ( 1 in all studied behaviours) resulted from the child's fear of dog that prevented him/her from establishing any form of contact and, therefore, inhibited the fulfilment of tasks. This situation required tailoring of the programme to the needs of the person and focus on the desensitization, that is slow exposition and accustoming to the presence of dog. The results obtained after the completion of the programme indicated small positive changes in the majority of the assessed behaviours. This, in turn, showed the person's acceptance of the dog's presence to the extent that enabled him/her to perform given tasks when the dog was around. This may lead to a conclusion that the ten-month programme tailored to the needs of the subject contributed to the person's functioning improvement in the "independence" field, and the achieved results were promising.

\section{Summary and conclusions}

Taking into account the analysis presented above it may be concluded that the ten-month kynotherapy programme contributed to the increase of the skills as far as certain independence-related behaviours in children with Down syndrome are concerned. Average results achieved by the subject after the completion of kynotherapy programme were considerably higher than the results obtained before the programme. None of the subjects exhibited regression in the analysed behaviours. The highest average improvement concerned the following three behaviours: "the child wants to participate in the therapy," "the child feeds the dog with the left and right hand," and "the child puts on and takes off the shoes." It indicates that the subjects were willing to participate in a therapy involving a dog. Such operations as taking off the shoes or feeding the dog became a constant element of a kynotherapy session. The child performing these operations signalled his/her readiness to participate in these sessions. It should be noted that all subjects in the group were well motivated to participate in the classes on their own $(25 \%$ did not change the motivation, $75 \%$ achieved average and high results). During kynotherapy classes, children, accompanied by a therapy dog and their peers, learned how to cooperate, make decisions, wait for their turn, compete, and deal with the situation of loss and winning. The children were more joyful and emotionally involved with the dog and the therapist and they undertook certain tasks. Therefore, kynotherapy proved to be an excellent occasion to bind together and integrate a class, especially when all pupils start their education.

After the completion of the programme, the subjects achieved a high average improvement in three other types of behaviours connected with responsibility: "the child combs the dog," "the child puts the toys and aids back in the box," and "the child sees the therapist and the dog off after the session." These results may be justified by the very functioning of people with Down syndrome who 
usually achieve better results in the fields of socialization, responsibility, and contacts [18.

A detailed comparative analysis of the initial and final results for the behaviours indicated that the three girls: O.N, Z.H. and P.D. regressed as far as the frequency of the behaviour "the child requires constant care and supervision during the session" is concerned. It is connected with the occurrence of the following behaviours: refusal to wait for their turn, stubbornness, refusal to perform certain tasks and follow instructions, problems with keeping the attention, compulsive behaviours - such as constant feeding of the dog. Such problematic behaviours negatively affect social functioning of the class. Nevertheless they constitute the phenotype of behaviours characteristic of Down syndrome. They may also result from an alleviated level of disorders and irregularities in different spheres of functioning [19].

The highest number of changes in the behaviours regarding "independence" was observed in the child who was at first afraid of the dog and achieved the lowest possible results. The scores obtained after the completion of the programme indicate small, yet positive, changes. It undoubtedly resulted from the subject's accepting the dog. It emphasizes the importance of a thorough analysis of the child's needs, possibilities, and especially reactions to the therapy dog. Only after the fear is eliminated, one can introduce kynotherapy and can expect the desired effects.

The effectiveness of kynotherapy in supporting the independence of people with Down syndrome is supported by the results obtained by the only subject with severe intellectual disability. This subject exhibited increments in nine out of ten behaviours. Such satisfactory effects may be a result of a parallel participation in other forms of therapy; however therapy is never based on one method only, and no therapeutic activity is isolated, separated from other forms. Kynotherapy is not a therapy in itself; it is a form of support for conventional therapeutic methods and rehabilitation. Therefore, in order for it to produce the desired results, it should be in line with other pedagogical and rehabilitation activities.

Summing up the discussion on the independence of children with Down syndrome through kynotherapy, the following conclusions could be drawn:

- Kynotherapy directed at supporting the independence of children with Down syndrome affects the child's functioning. It may encourage the child's development and help to overcome deficiencies. When dealing with an animal, the child builds up the sense of independence, bravery, self-confidence, and he/she improves the attention span.

- Therapy dog may become a creator of the child's world in which the child develops his/her cognitive and social skills.

- Kynotherapy is not only a method, or a form of therapy or rehabilitation. It is also a source of joy and pleasure for children with disability. The classes held with the participation of a dog are based on a directed games conditioned by such predictors as: child's willingness and the need to play, mood, space, examples, and the behaviour of the dog and the therapist. During such therapeutic games, people with Down syndrome may feel free from the paralysing fear of dog that sometimes can be destructive.

- Involving the child with Down syndrome in kynotherapy, one has to remember that the child cannot be made to participate in any, even the most attractive, activity. According to [20] sometimes a child that seems to be stubborn will exhibit a delayed response and start the activity he/she finds interesting. There can be no tensions and negative emotions attached, since otherwise it may cause trauma or aversion.

- Each child with Down syndrome, regardless of the limitations, can self-actualize. Deprived of the possibility of be autonomous, the child becomes passive, bored and unwilling to experience new things.

\section{References:}

1. Szczepkowska-Szczęśniak K, Uniszewska K. Osiąganie samodzielności. Droga do samodzielności. Przygotowanie na przyjęcie dziecka ze specjalnymi potrzebami edukacyjnymi. Warszawa; 2006.

2. Obuchowska I. O autonomii w wychowaniu niepełnosprawnych dzieci

i młodzieży.[W]: Dykcik (ed.), Społeczeństwo wobec autonomii osób, Poznań; 1996.

3. Dykcik W. Problemy autonomii i integracji społecznej osób niepełnosprawnych

w środowisku życia. [W]: Dykcik (ed.) Pedagogika specjalna Poznań; 1997

4. Wojciechowska B.(2008), Terapia Feuersteina [W:] B. Kaczmarek (ed.), Wspomaganie Rozwoju dzieci z zespołem Downa - teoria i praktyka praktyka Kraków; 2008.

5.Pueschel SM. Ku lepszej przyszłości. Zespół Downa. Przewodnik dla rodziców i Opiekunów. Zakrzewo; 2008. 
6. Wiśniewska M. Wspomaganie rozwoju dziecka z niepełnosprawnością intelektualną. Poradnik dla rodziców i terapeutów Kraków; 2010.

7. Kaczmarek BB.Wspomaganie rozwoju dzieci z zespołem Downa - teoria i praktyka, Kraków; 2008.

8. Minczakiewicz M. Jak pomóc w rozwoju dziecka z zespołem Downa. Poradnik dla rodziców i wychowawców Kraków; 2001.

9. Korczyński M. Możliwości terapeutyczne zwierząt. Zeszyty Naukowe WSSP. 11; 2011

10. Kazdin, AE. Single - Case Research Designs, New York; 1982.

11. Limond JA, Bradshaw JWS, Cormack, KFM. Behaviour of children with learning disabilities interacting with a therapy dog, Anthrozoos; 10: 997.

12. Esteves SW, Stokes T. Social effects of a dog's presence on children with disabilities, Anthrozoos. 2008; 21(1).

13. Popiołek J. Kynoterapia (dogoterapia) jako naturalna forma wspierania rehabilitacji i terapii dzieci z niepełnosprawnością" [w:] Mazur A, Fatyga M, ed. Sprostać wyzwaniom. Rodzina w obliczu długotrwałej choroby i niepełnosprawności Stalowa Wola; 2012.

14. Kulisiewicz B. Witaj Piesku! Dogoterapia we wspomaganiu rozwoju dzieci o specjalnych potrzebach edukacyjnych Kraków; 2007.
15. Machoś-Nikodem M. Rola kynoterapii (dogoterapii) w usprawnianiu komunikacji małego dziecka $\mathrm{z}$ deficytami rozwojowymi [in:] Włodarczyk-Dudka M, ed. Terapia psychopedagogiczna $\mathrm{z}$ udziałem psa - wybrane zagadnienia. Ostróda; 2006.

16. Włodarczyk-Dudka M. Rehabilitacja osób z niepełnosprawnością wielozakresową

z udziałem zwierząt [in:] Ćwirynkało K, Kosakowski $\mathrm{Cz}$, ed. Rehabilitacja i edukacja osób z niepełnosprawnością wielozakresową, Toruń; 2012.

17. Pawlik-Popielarska B. Terapia z udziałem psa. Gdańsk; 2005.

18. Zasępa E. Psychologiczne funkcjonowanie osób $\mathrm{z}$ zespołem Downa), Wydawnictwo APS, Warszawa - Kraków; 2008.

19. Żyta A. Osoby z zespołem Downa. [In:] Ćwirynkało K, Kosakowski Cz, ed. Rehabilitacja i edukacja osób z niepełnosprawnością wielozakresową.2012.

20. Machoś-Nikodem M. Dogoterapeutyczny program polisensorycznej stymulacji porozumiewania się. Warszawa; 2007.

\section{Correspondence address:}

Dr hab. Mariusz Korczyński, tel. 501473480,

e-mail: m-korcz@wp.pl 